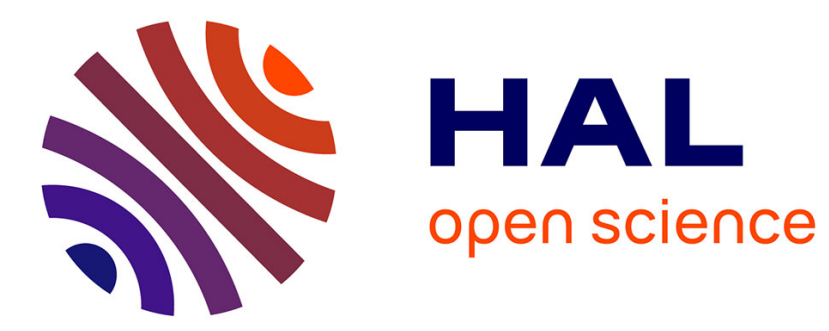

\title{
A digital introspection of a mummy cat
}

Ronan Gaugne, Stéphanie Porcier, Théophane Nicolas, François Coulon, Odile

Hays, Valérie Gouranton

\section{To cite this version:}

Ronan Gaugne, Stéphanie Porcier, Théophane Nicolas, François Coulon, Odile Hays, et al.. A digital introspection of a mummy cat. Digital Heritage 2018 - 3rd International Congress \& Expo, IEEE, Oct 2018, San francisco, United States. pp.1-8. hal-01875690

\section{HAL Id: hal-01875690 https://hal.science/hal-01875690}

Submitted on 18 Sep 2018

HAL is a multi-disciplinary open access archive for the deposit and dissemination of scientific research documents, whether they are published or not. The documents may come from teaching and research institutions in France or abroad, or from public or private research centers.
L'archive ouverte pluridisciplinaire HAL, est destinée au dépôt et à la diffusion de documents scientifiques de niveau recherche, publiés ou non, émanant des établissements d'enseignement et de recherche français ou étrangers, des laboratoires publics ou privés. 


\section{A digital introspection of a mummy cat}

\author{
Ronan Gaugne \\ Univ Rennes, Inria, CNRS, IRISA \\ Rennes, France \\ Email: ronan.gaugne@irisa.fr
}

\author{
François Coulon \\ Musée des Beaux-Arts de Rennes
}

Rennes, France

\author{
Stéphanie Porcier \\ Laboratoire CNRS HiSoMA \\ (UMR 5189_MOM) \\ Lyon, France \\ Univ. Paul-Valéry, Labex \\ ARCHIMEDE \\ Montpellier, France
}

\author{
Odile Hays \\ Musée des Beaux-Arts de Rennes \\ Rennes, France
}

\author{
Théophane Nicolas \\ Laboratoire CNRS Trajectoires \\ (UMR 8215) \\ Inrap \\ Rennes, France
}

\begin{abstract}
In the last decade, made more accessible by the trivialization of new medical imaging technologies, research on the study of animal mummies of Ancient Egypt is becoming more and more important, leading to a better understanding of the History and Culture of this civilization. Additional new 3D technologies such as virtual reality, augmented reality and 3D printing allow to enrich the research process and open innovative possibilities for scenography in scientific mediation. The work in this paper focuses on one particular mummy cat and combine $C T$ scan, $3 \mathrm{D}$ printing and augmented reality in a global process to accompany and support at the same time a scientific study of the object and a preparation of a mediation action in a Museum.
\end{abstract}

Keywords- Egyptology, Mummy cat, CT scan, 3D printing, Projective augmented reality.

\section{INTRODUCTION}

For more than a millennium ( $c$ a $900 \mathrm{BC}-\mathrm{AD} 300)$, the ancient Egyptians mummified millions of animals throughout Egypt, a manifestation of the popularity of sacred animal cults [17]. Diverse species of animals, including cats, dogs, baboons, birds, fishes and crocodiles were mummified and buried in collective tombs or catacombs as 'votive' offerings to a particular deity [9], [17]. The first studies on animal mummies date from the Egyptian campaign led by Napoleon Bonaparte in the late eighteenth century and have been studied since sporadically [24], [25], [26], [36]. These macroscopic and invasive analyzes were essentially intended to inform us about mummification techniques and to provide a panorama of the fauna of ancient Egypt.

Medical imaging such as radiography, CT scan and less frequently MRI have revolutionized the study of mummies and are widely used since decades. The first $X$ rays radiography of a mummy was performed in 1896 [21], only a few months after the discovery of X-rays by Wilhelm Conrad Roentgen in December 1895, the first CT scan of a mummy's brain [23], and the first whole-body scan of a mummy [16] were performed in 1977 barely two years after the development of this technique for medical imaging.

In recent years, made more accessible by the trivialization of new medical imaging technologies, research on the study of animal mummies is becoming more and more important internationally (cf. [1], [14], [19], [31], [27], [30], [32], [8], [35], [15], [40], [13], [18], [42]).

Recent works integrate additional technologies such as 3D printing in order to produce physical copies of internal

This work was partially funded by the ANR-16-FRQSC-0004 INTROSPECT project and by MAHES Project supported by the Agence Nationale de la Recherche from the «Investissement d'Avenir » program ANR-11-LABX-0032-01 LabEx ARCHIMEDE. pieces identified by CT scan [28], [38], [13] for both scientific research and mediation in Museum context. 3D interactive rendering of mummies was also used in Museums, on tactile screens, with the product Inside Explorer [41]

The work presented in this paper proposes a contribution at two levels. First, we contribute to the knowledge of Egyptian animal mummies, with the study of one particular mummy with interesting characteristics, using CT scan. Second, we extend the study using two technologies of interactive 3D, 3D printing and projective augmented reality, with a concern of deployment in a museum context.

\section{CONTEXT}

\section{A. The mummy cat}

The mummy cat at the heart of this study belongs to the Musée des Beaux-Arts de Rennes since 1923, after a deposit from the Musée du Louvre (Fig. 1). It came from the Cabinet des Médailles of the National Library of France. Its original provenance is not known. It is kept in the museum under inventory number D.1923.2.108.

The mummy is complete and can be classified in the category of "skittles mummies". It is $42 \mathrm{~cm}$ high and 10.3 $\mathrm{cm}$ long. The head mimics the appearance of a cat (muzzle, eyes and large erect ears). The wrappings are well preserved. On the upper layers, two pieces of linen cover the head on which two textile buttons reproduce the eyes of the cat. On the front face, under a net with large mesh, the rest of the body presents a geometrical "decoration" fashioned by 15 bicolored quadrilaterals (unbleached textiles, and dark brown textiles for the latter, are soaked with blackish resinous products which make them friable). At the back of the mummy, these layers are covered with a large piece of linen. Three dark brown strips surround the neck of the animal.

Subsequently to a study made in the University of Manchester on about 800 mummies of animals, which showed that about one third of these mummies are empty [30], the Museum decided to analyze its mummy thanks to radiography. This examination was carried out in a veterinary laboratory and showed that the mummy was not empty. Nevertheless, it also showed that the mummy did not contain a full skeleton of a cat but an assembly of bones originating from at least three felines (Fig. 2). The radiography showed that there is no skull in the mummy but gave no clue on the constitution of the head. 


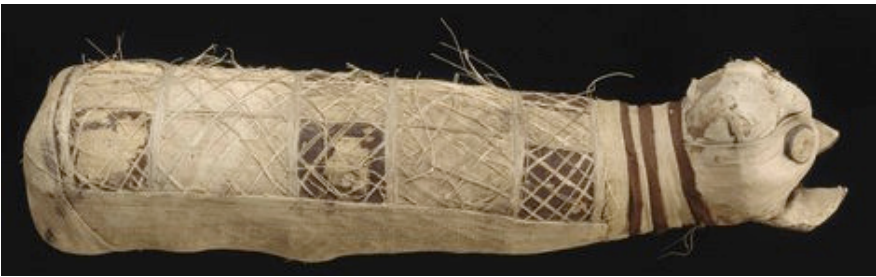

Figure 1. The mummy cat of the Museum

It was then decided to investigate further with the help of two multidisciplinary research projects, INTROSPECT and MAHES.

\section{B. The project INTROSPECT}

The interdisciplinary INTROSPECT project involved in the study is an international project that aims to develop, for archaeologists, new uses and tools that facilitate access to new knowledge through interactive numerical introspection methods that combine computed tomography with 3D visualization technologies, such as virtual reality, tangible interactions and $3 \mathrm{D}$ printing. It is a collaboration between researchers in computer science, archeology, and museums. The scientific heart of the project is the systematization of the relationship between the artifact, the archaeological context, the digital object and the virtual reconstruction of the archaeological context that represents it and its tangible double resulting from the 3D impression.

\section{The project MAHES}

The multidisciplinary research project MAHES has been established by many international partners and in particular, the University of Montpellier and the CNRS Laboratory "Archaeology of Mediterranean Societies » (Montpellier, France), which is working on the collection of animal mummies kept in the Musée des Confluences at Lyon, the greatest outside Egypt, in order to study the worship of sacred animals through its ritual practices and beyond, better know the History and Culture of ancient Egypt.

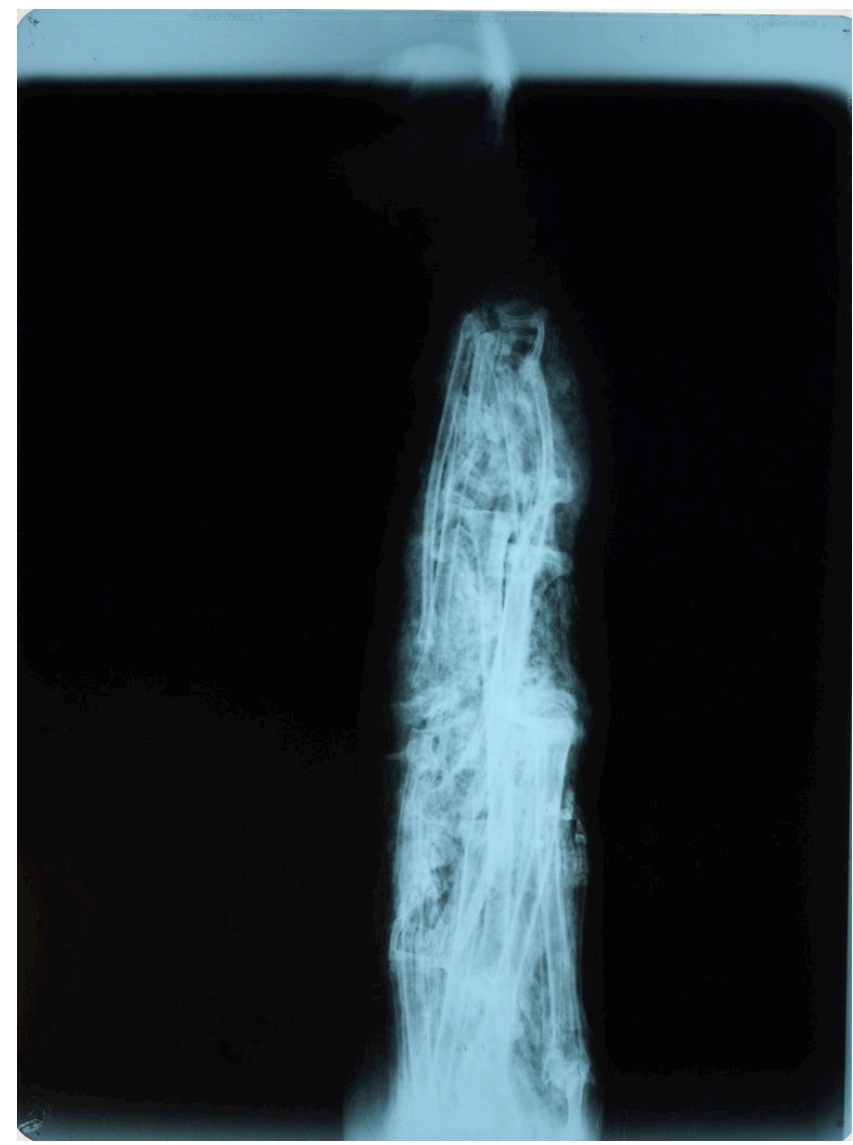

Figure 2. Radiography of the mummy.

\section{Methodology OF THE STUDY}

The methodology of the study presented in this paper is based on a global process which integrates new technologies in the scientific work of $\mathrm{CH}$ practitioners.

\section{A. General process}

This process is centered on the $\mathrm{CH}$ material (Fig. 3). The material is transmitted to the imaging laboratory to be explored by the CT scan, or digitized by photogrammetry, laser scan or other digitization techniques.

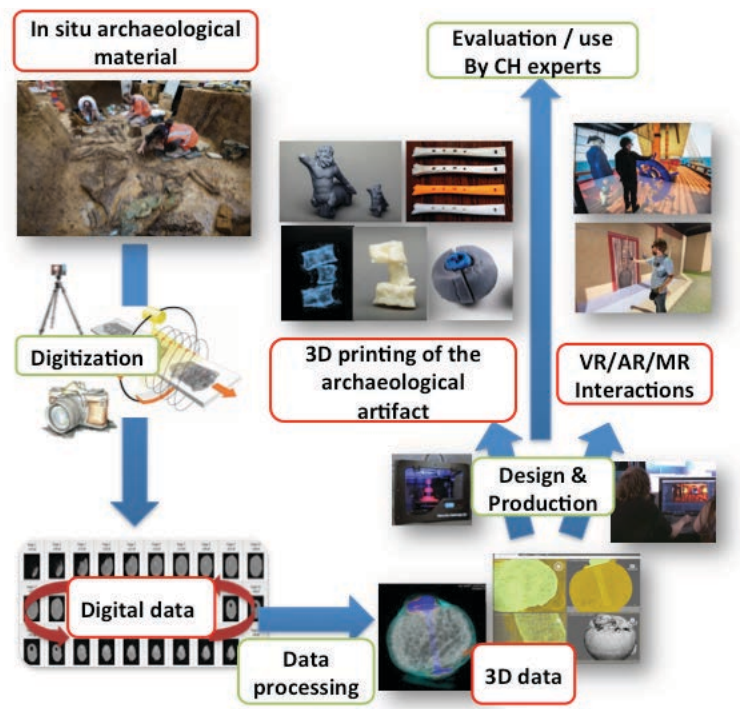

Figure 3. Global process of the study. 
The data collected during this step, in DICOM format [33] in the case of a CT scan, allow several possible exports through post-processing: analysis, $3 \mathrm{D}$ volume rendering and mesh generation for $3 \mathrm{D}$ printing. CT scan or tomodensitometry allows cut-away views of an object (tomo) and analysis of its composition (densito). The slices, which are $2 \mathrm{D}$ images, can be stacked to reconstitute the volume of the object. It can then be digitally seen from all angles, virtually sliced with respect to different axis, or segmented according to specific focuses.

\section{B. Technical environment}

The CT scanner used in this study is a Siemens SOMATOM sensation 16 (Fig. 4) owned by a private company who delivers services and expertise on X-Ray images and associated tools.

The three-dimensional explorations were performed through two passes (acquisition) and 2D/3D images postprocessing. The two acquisitions were a topogram (or radio mode) for positioning the slices to be realized and a helix scan, with $80 \mathrm{kV} / 50 \mathrm{mAs}$. An additional scan was performed on the head part of the mummy, with $100 \mathrm{kV} /$ 187 mAs.

The scan generates a dataset under DICOM format of $512 \times 512$ pixels $2 \mathrm{D}$ slice images, with 879 slices for the whole mummy and 235 slices for the head.

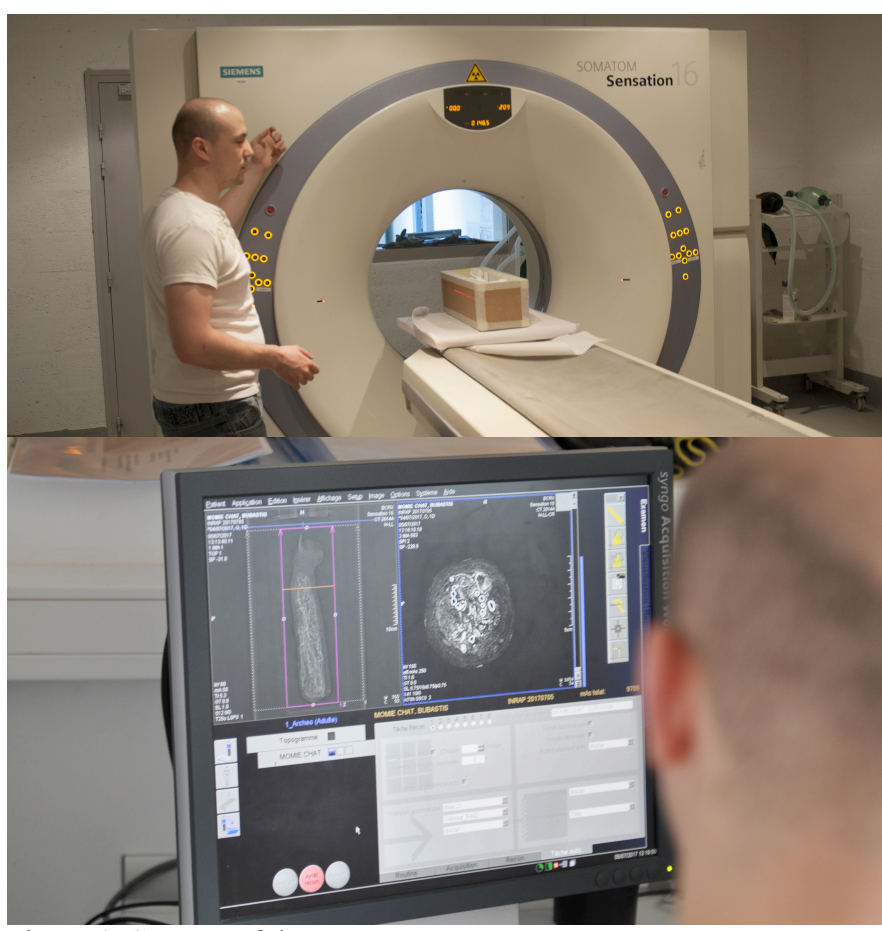

Figure 4. CT scan of the mummy cat.

\section{RESUlts OF THE STUDY}

\section{A. Observations from CT Scan}

The content of the mummy is composed of several bone remains of felids that are grouped at the "body" part of the object (Fig. 5). We can identify a scapula, a humerus, a radius, an ulna, a complete hand (carps, metacarpus and phalanges), two coxals, two femurs, five tibias, two fibulas, four complete hind legs (tarsi, metatarsals and phalanges), one lumbar vertebra and two sets of six caudal vertebrae corresponding to a minimum of three individuals. Note, however, the absence of ribs, cranial remains and mandibles. The fact that no bones are in anatomical connection indicates that the animals remains were in a state of advanced decomposition, which is confirmed by the characteristic holes caused by necrophagous insects and observed by the scanner. The size of the bone remains as well as the absence of synostosis at the distal and proximal ends of both femurs and five tibias suggest that they are young individuals.

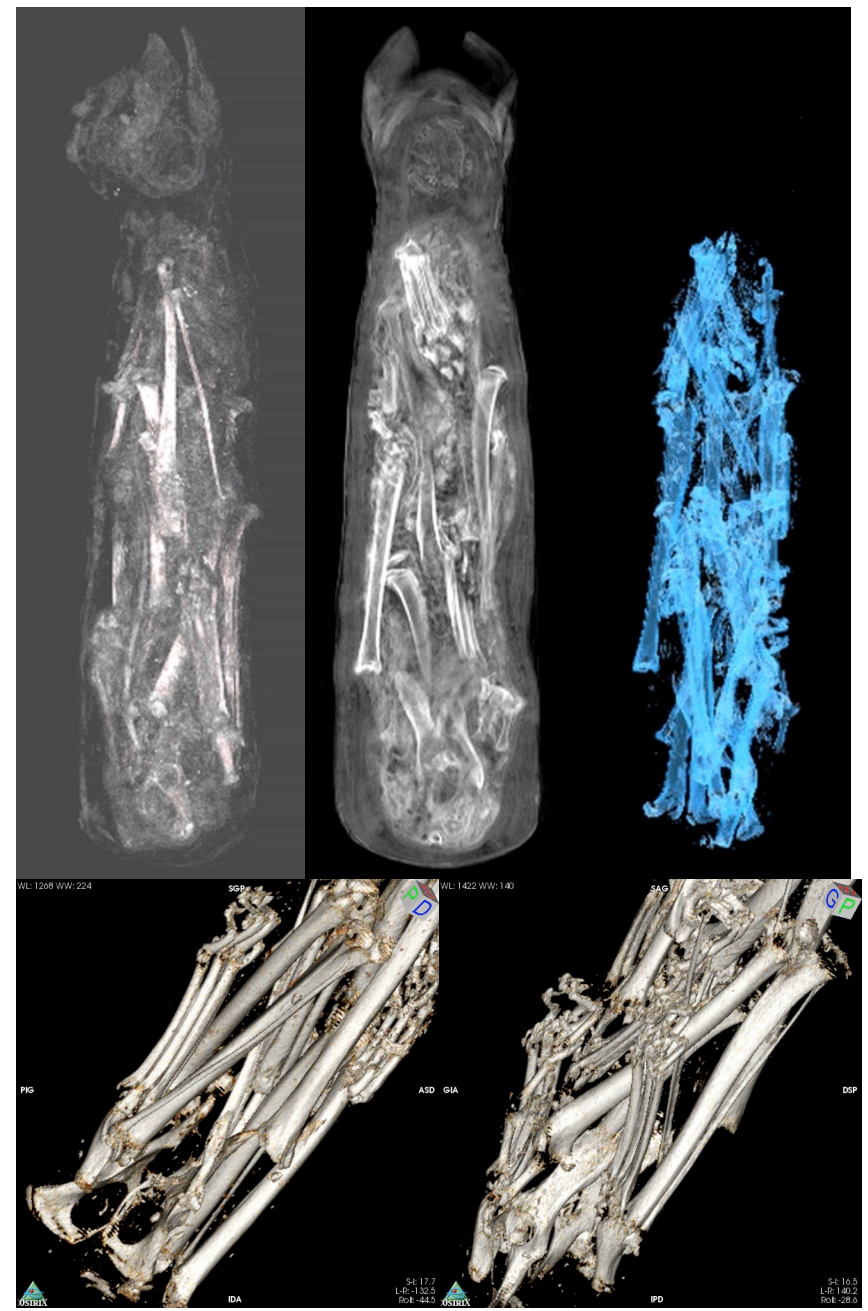

Figure 5. Volume rendering of the mummy. Top: Two cat paws are visible at the bottom of the left image, another one at the top of the center image. The right image is a segmentation of the agglomerate of bones. Bottom: Volume rendering of the bones, with views of two coxals (left, bottom) and complete hind legs.

The mummy's head, empty of all animal matter, contains a ball of textile (Fig. 6). It is a ball of yarn in S twist, fiber not determinable, whose section is about 1 millimeter. 


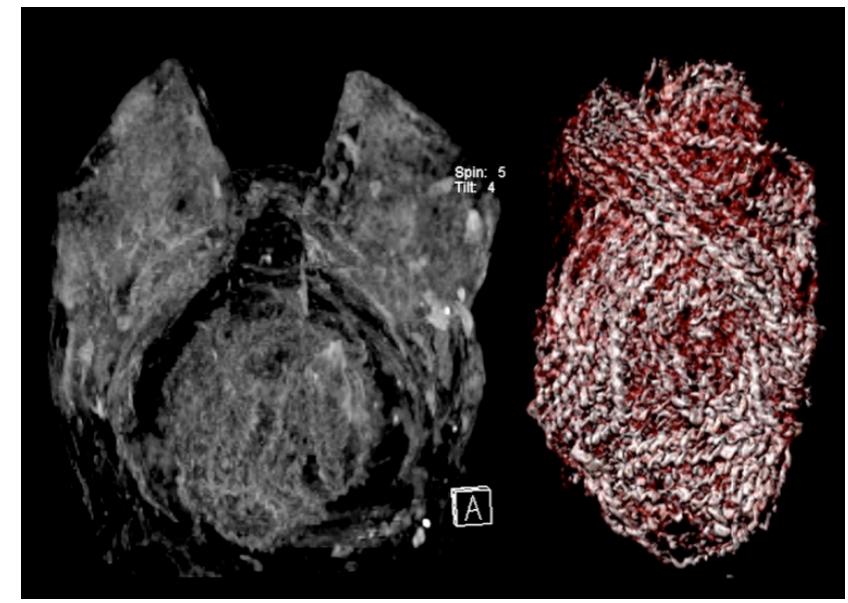

Figure 6. Scan of the head with a segmentation and volume rendering of the ball of string that shapes the head of the mummy cat.

\section{B. Comparative study}

The rare $\mathrm{C} 14$ dates have shown that the geometric "decorations", well attested elsewhere, seem to appear before the Ptolemaic period [22], [37], [2], [3], [4], whereas they are generally exclusively associated with the Roman period [5], [20]. To propose a dating on a simple stylistic criterion proves therefore relatively hazardous as the textiles "move" easily, to use the words of Fleur Letellier-Willemin [22]. In the absence of $\mathrm{C} 14$ dating done on the mummy of our study, we propose the widest possible dating between the middle of the first millennium BC and the IVth century. A.D.

At first glance, the very neat outer appearance of the mummy could denote with its content composed of partial remains of several cats. It is not uncommon to note that carefully decorated mummies contain fragments of animal bodies (or no animal remains) (e.g., cf [5], [20]) and, conversely, mummies of a simple, even crude, shape, containing anatomically complete individuals (e.g., cf [20]). The container is frequently in the image of the intended divine entity. The head is very often the most neat and the most developed part, whatever the content of the mummy [22]. It is sometimes modeled from several layers of superimposed textiles having padding vocation which is undoubtedly the case of the ball discovered at the level of the head of the mummy of Rennes.

The absence of a complete body in a perfect state of conservation has raised questions about the status of these mummies. Egyptology has classified this type of artifact as "fake mummies" or "pseudo-mummies" (e.g. cf. [7], [11], [10], [12], [6], [1], [27]). Various explanations have been proposed: products of a scam of credulous pilgrims organized by unscrupulous priests [10], [12], or lack of dead animals, raw material necessary for making mummies [10], [39], [42]. "Composite" mummies, free from animal matter or containing several pieces of animal, would account for about $30 \%$ of the objects [30]. Note, however, that this proportion is difficult to apply to all the mummies that have been deposited in Egypt. This percentage has been proposed by the Manchester team from the study of mummies preserved in various museum collections, but these are not potentially representative. Reducing this kind of mummies to the status of false / pseudo-mummies has the effect of marginalizing a large part of the "votive" mummies. Another hypothesis advanced by some, that of the concept of pars pro toto, would be that only one part of an animal would be enough to "sanctify" the object [7], [29] but this requires still to be substantiated.

It is certain, from reading the various studies on the subject, that the symbolic dimension of these objects is absolutely not understood. Unlike the category of mummies made using a single complete body, it is not the integrity of the body that was sought after, the fragments (or absence) of animal bodies not intended to be reborn in the afterlife. It is clear that this type of mummy therefore has other functions that have yet to be specified.

\section{DIGITAL PROCESSING FOR MUSEOLOGY}

The DICOM data obtained from CT scan was exploited in order to generate $3 \mathrm{D}$ data usable for both $3 \mathrm{D}$ printing and augmented reality. The goal of this part of the work was to propose new modalities for the exploitation of these data related to the internal structure of the mummy, both for scientific study purposes and dissemination in a museum context.

\section{A. $3 D$ printing}

The data collected during the CT scan allowed to reconstruct at the same time the external shape of the mummy with an excellent accuracy, and also, the shape of internal elements, by combining segmentation and density information. Three different meshes were generated from the DICOM data, using the open source software Horos (https://horosproject.org/), the external shape of the mummy, the bones, and the ball of string of the head (Fig. 7).

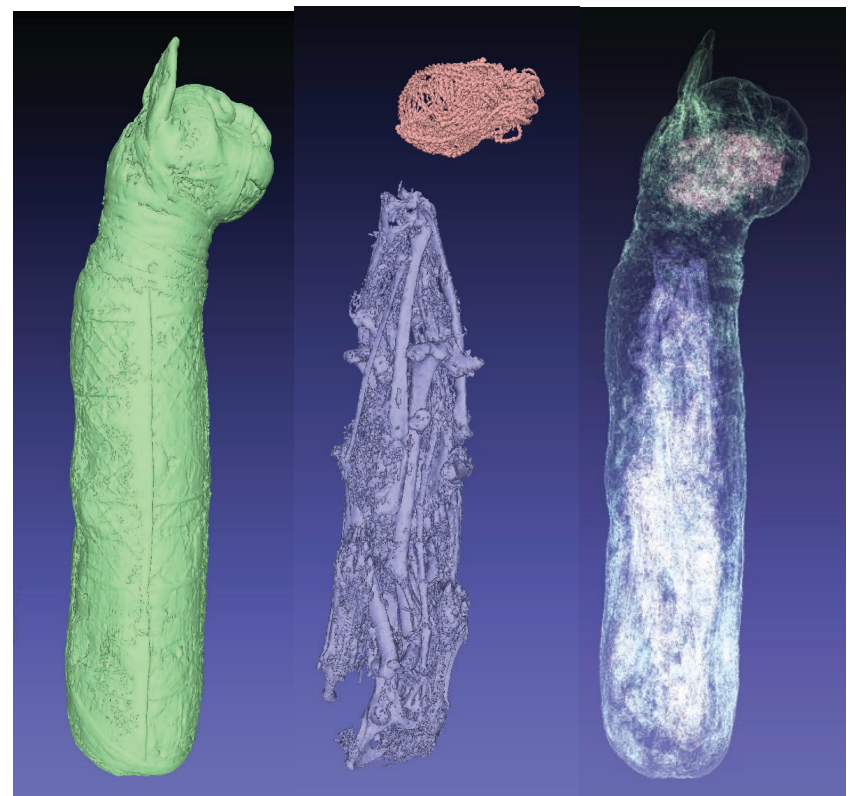

Figure 7. Left: mesh of the external shape. Center: meshes of the bones (purple) and of the ball of string (red). Right: rendering of the 3 meshes with the x-ray shader in Meshlab.

The three meshes were then 3D printed using a Raise3D N2 Dual Plus owned by the computer science research institute. This $3 \mathrm{D}$ printer is able to print a volume of $305 \mathrm{~mm} * 305 \mathrm{~mm} * 610 \mathrm{~mm}$, which allow to print the whole mummy at scale 1:1 in a single piece (Fig. 8). The external surface of the 3D model of the mummy was smoothed in order to serve as a projection surface in the AR system described in the next section. The meshes of the bones and 
the ball of string were also printed with the purpose to enrich the exhibition of the mummy in the Museum (Fig. 9).

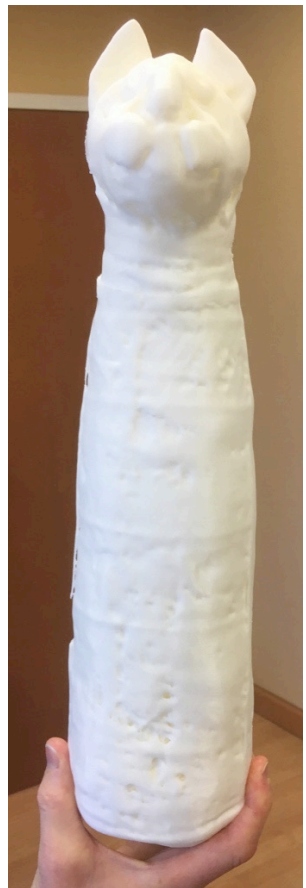

Figure $8.3 \mathrm{D}$ printing of the mummy cat.
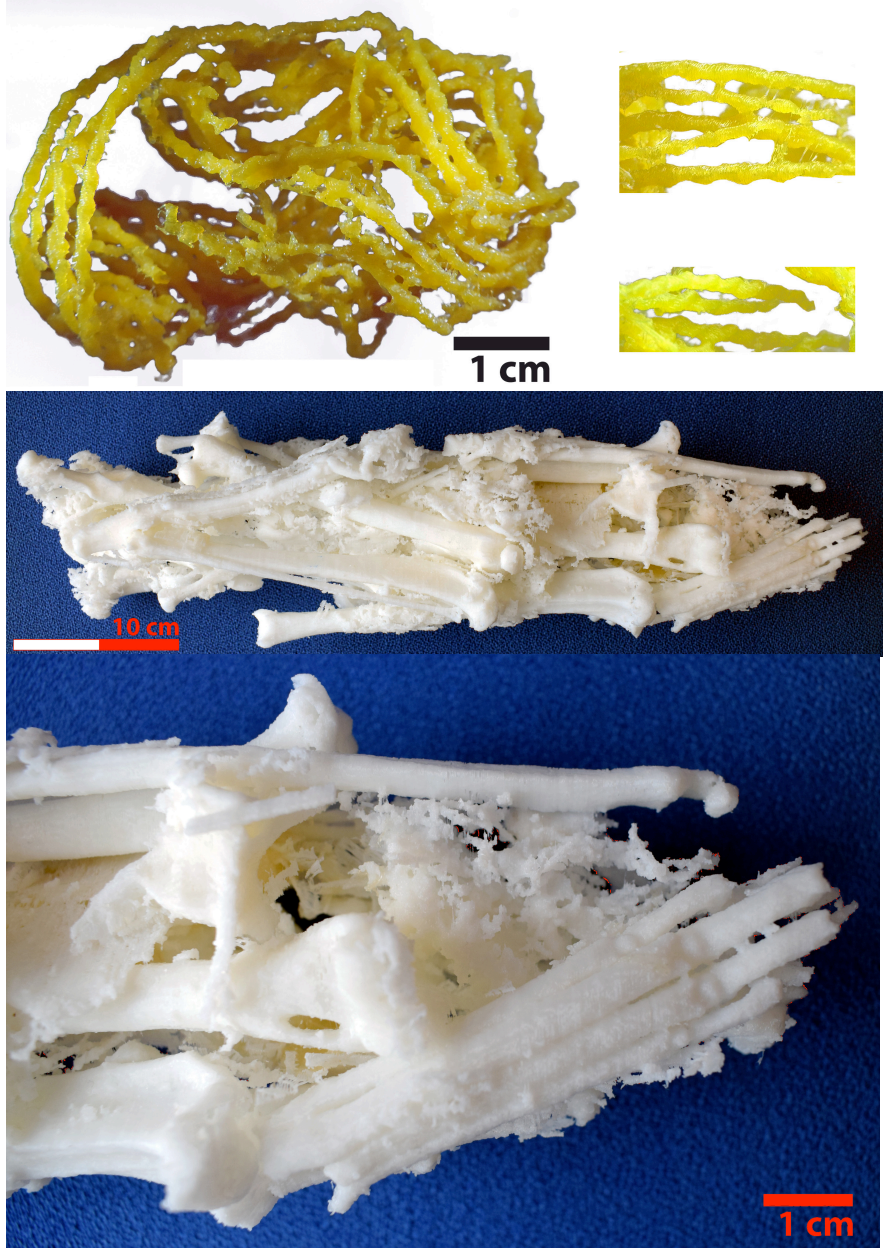

Figure 9. Top: 3D printing of the ball of string. Middle: 3D printing of the bones. Bottom: Detail of the 3D printing.
A 3D printing of the whole mummy, with a transparent body and colored internal parts, as proposed in the work [34] on a funeral urn, is under preparation, also to enrich the Museum exhibition.

\section{B. Augmented reality}

The 3D data generated from CT scan was also integrated in a projection-based augmented reality system. The principle of the system was to project the internal content of the mummy on the $3 \mathrm{D}$ printing of the mummy (Fig. 10) Two main problematics had to be addressed with such system. First, the projection must fit the shape of the surface, and second, the projection must take into account the point of view of the user as the content displayed is the internal structure of the mummy and not only its external surface, as it is generally the case in projective AR.

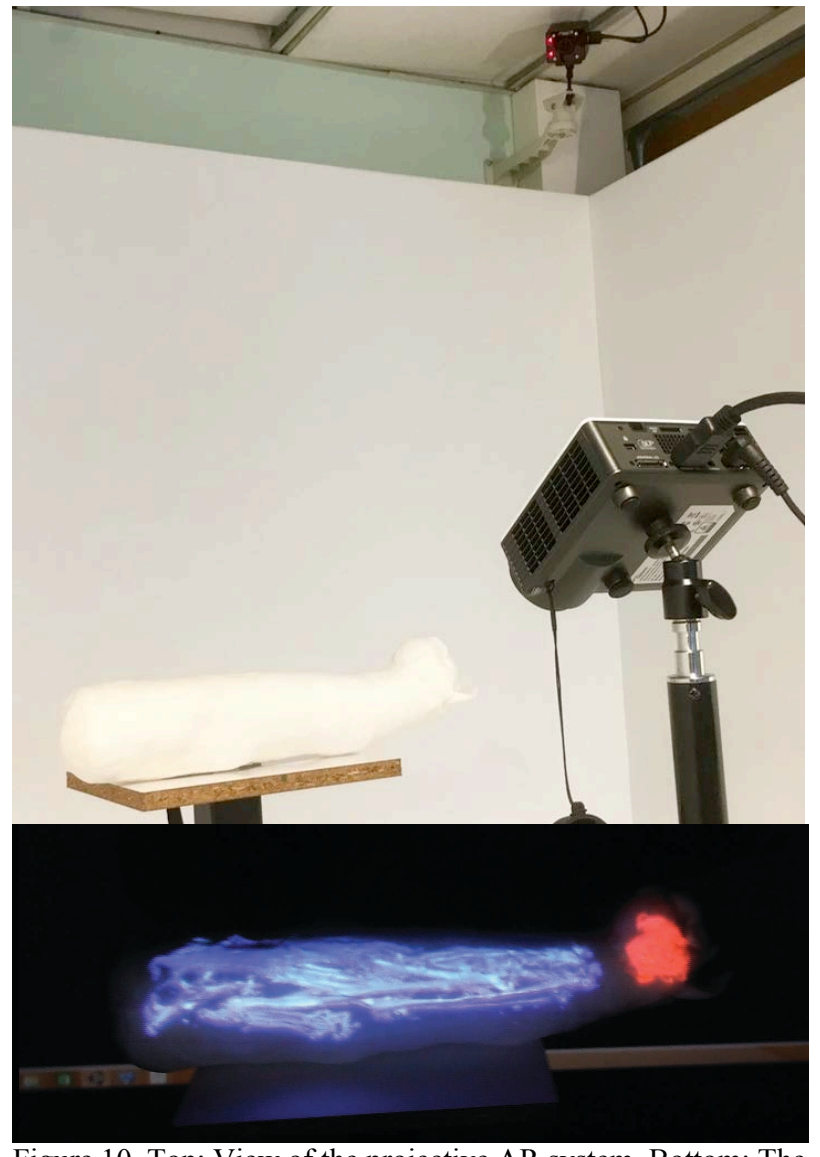

Figure 10. Top: View of the projective AR system. Bottom: The bones and the ball are displayed on the 3D printed copy of the mummy.

The setup of the system is the following: the application that manages the display of the 3D content was developped in Unity 3D. The image is projected on the 3D printed copy of the mummy using a pico-projector Optoma ML750ST. User's point of view is tracked using an ART TrackPack system with 2 infrared cameras, and a marker positioned on the head of the user. A marker was also positioned on the back of the copy of the mummy in order to define the position of the $3 \mathrm{D}$ model of the mummy, and another one on the videoprojector for the calibration phase. The adaptation of the projected image to the 3D surface of the mummy is a combination of homographic tranformation and Unity "Projector" object. The user's point of view, captured from a Unity "Camera" Object attached to the head 
position, is turned into a texture sent to the Projector object and transferred to another Unity "Camera" object corresponding to the videoprojector.

\section{DISCUSSION}

The different technologies used in this work, CT scan, 3D printing and augmented reality, offered added value at two level. First, it improved the scientific process in the study of the object, and second, it opened innovative opportunities in the mediation activity of the Museum.

The CT scan provides a very good visualization of the structure of the strips, the bone mass, as well as the pelota allowing to make findings (state of the epiphysis, necrophagous holes) and measurements on the bones. However, most of these osteological findings can only be made by an archaeozoologist experienced in diagnostic tomography (characterization of bones from sections), as well as the mastery of DICOM imaging treatment tools.

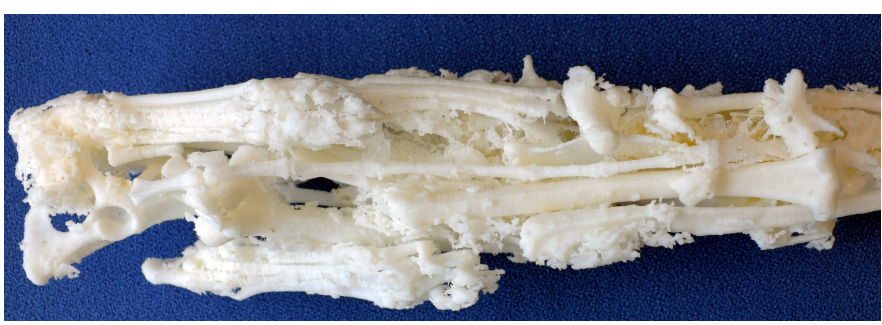

Figure 11. View of the tail vertebrae, in the center of the 3D printing.

The 3D printing of the bone mass allows a different apprehension of these elements. It is precise enough to allow the same observations or observations on the visible bones even for the smallest (phalanges) and the least dense from the point of view of X-ray analysis (tail vertebrae for example, Fig. 11); in fact, it allows an archaeozoologist devoid of imaging training to do his analysis as he would on real bones. Similarly, the impression of the ball makes it possible formally to identify a twist in $\mathrm{S}$ of the thread, and to make a comparison with balls found in context (Fig. 12), the similarity in the twisting of the thread and the ordering of the ball makes it possible to hypothesis that it is a ball of flax fiber.

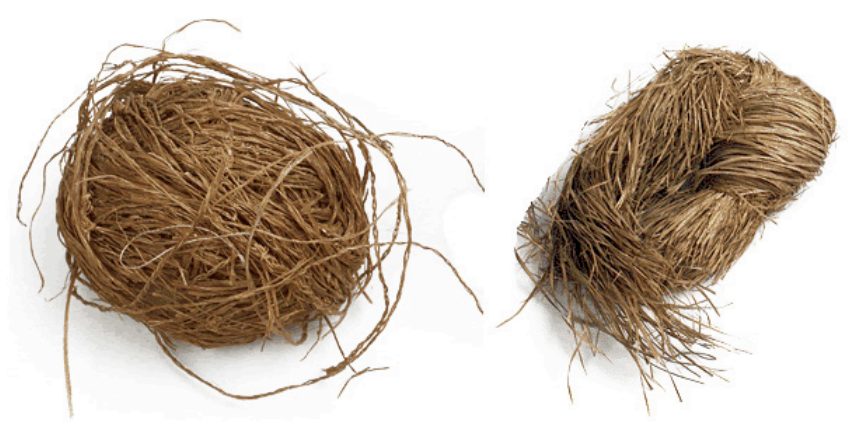

Figure 12. Examples of balls of linen found in Egypt. Left: Ball of braided linen. Right: Knotted linen fiber.

Beyond specialists, 3D printing allows everyone a very good visualization and perception of bones, and the identification of anatomical elements such as legs, hands and tails, indicating that it is a cluster complex with several individuals.

The scenographic and educational exploitation within the museum of this research must now be thought out according to the new possibilities offered by $3 \mathrm{D}$ printing and augmented reality. The presence of educational tools based on new technologies is a recurring question for every proposition: What does this technology bring to the perception of the object from the point of view of the museum's issues and what are the risks of diverting, in fine, the visitor of the direct relationship he has with it?

At a time when mediation in archeology tries to give access to a better understanding of the object, how to make appear what is not visible from the beginning, and allow the visitor to enter the mysteries of this mummy? We think especially of young audiences for whom the understanding of what a mummy is really obscure. The child has trouble distinguishing the cat mummy from a cat statue. This is the reason why a reflection is underway to consider the communication of these new discoveries, from the material provided by the new technologies.

Three proposals enter into a process of readability of the work, make it possible to give access to a documentation hitherto reserved for the experts without compromising the individual emotion. As such they differ totally from an application to download on phone or tablet that could make the visitor captive technique.

The 3D impressions of the bones and the string ball of the mummy give an immediate representation of its internal structure easily accessible for a general public, including young. Moreover, the museum, confronted with conservation missions, forbids the touch of the object, with the exception of the staff responsible for moving the works and the blind public for whom three-dimensional reproductions have been designed. This module offers the possibility of tactility and manipulation for all and promotes a movement of look back and forth between the original, put at a distance in a window, and the model in 3D.

The planned transparent 3D printing represents a complementary path that directly links the original object and its internal spatial structure. Augmented reality adds an interaction with the digital environment that enhances the interest of young audiences. The quality of this proposal gives an overall picture of the process of creating the mummy for all audiences.

Nevertheless, the system proposed in this work requires additional work to meet the constraints of a museum, particularly in terms of robustness in the face of intensive use, but also in terms of cost. The use of a Hololens-type mixed reality helmet could be an interesting alternative even if existing systems on the market remain expensive.

\section{CONCLUSION}

Archaeological remains are fragile witnesses to analyze, interpret, preserve and enhance. These complex tasks are metamorphosed in the digital age. New technologies have become particularly important in recent years, particularly in imaging, additive manufacturing, virtual reality and augmented reality. Acquisition technologies such as computed tomography offer the possibility of preserving the 
integrity of the works, while allowing a virtual introspection of the contexts or objects, to identify the nature of the materials, the internal structures of the objects. The combination of technologies, such as $3 \mathrm{D}$ printing or RA, offers the ability to transform $3 \mathrm{D}$ renderings based on digital CT data into physical and interactive objects. The individual thus has access to the possibility of rendering tangible a non-visible and non-accessible object, of decomposing a composite part or of changing scales for models of reduced size... This process is used for the long-term archiving of furniture, status report, and allows to study and replicate all or part of an object for study or valuation purposes for all audiences. This process of acquisition, digital data processing and prototyping has the advantage of being very fast and cost-effective. In a museum or educational setting, the RA, in addition to the general public's appetite for new technologies, highlights the importance of the interaction and the information offered for the valorisation of the results of the research. The system is presented on video: https://vimeo.com/288733541

\section{ACKNOWLEDGMENT}

The authors whish to thank Archibald Poisson from BCRX company for the work on CT scan, Quentin Petit, engineer at Inria, Francois Gauthier, Alexandre Bonnin, Tanguy Fournier, Mathilde Gouret, and Alexis Geffroy, students at INSA Rennes, for their work on projective augmented reality, Guillermo Andrade-Barroso for his help on 3D printing.

\section{REFERENCES}

[1] Atherton-Woolham, S. D., \& Mcknight, L. 2014. Post-mortem restorations in ancient Egyptian animal mummies using imaging. Papers on Anthropology, XXIII(1), 9-17. DOI: 10.12697/poa.2014.23.1.01

[2] Bleiberg E. 2013. 'The Problem with animal Mummies', in: E. Bleiberg, Y. Barbash and L. Bruno, Soulful Creatures: Animal Mummies in Ancient Egypt. Brooklyn, p. 65 notice 53.

[3] Brooklyn Museum, "Ibis-Form Mummy in Jar", Charles Edwin Wilbour Fund 37.1952Ea-c, brooklynmuseum.org, [Online]. Available :

https://www.brooklynmuseum.org/opencollection/objects/118456 [Accessed: May. 15, 2018]

[4] Brooklyn Museum, Ibis Mummy, Brooklyn Museum Collection X1179.4, brooklynmuseum.org, [Online]. Available : https://www.brooklynmuseum.org/opencollection/objects/184724 [Accessed: May. 15, 2018]

[5] Bruno L. 2013. 'The Scientific Examination of Animal Mummies', in: E. Bleiberg, Y. Barbash and L. Bruno, Soulful Creatures: Animal Mummies in Ancient Egypt. Brooklyn, pp. 122-123 notices 100-102.

[6] Bussi S. 2018. 'Économie du culte des animaux sacrés en Égypte hellénistique et romaine', in St. Porcier, S. Ikram, St. Pasquali (Eds.), Creatures of Earth, Water, and Sky. Essays on Animals in Ancient Egypt and Nubia. Proceedings of the International Symposium on Animals in Ancient Egypt, ISAAE 1 (01-04 Juin 2016, Lyon/France).

[7] Charron A. 2014. "De bien particulières momies animales », in G. Tallet, Chr. Zivie-Coche, Le myrte et la rose. Mélanges offerts à Françoise Dunand par ses élèves, collègues et amis, CENiM 9, pp. 229-247.

[8] Cornelius I., Swanepoel L.C., Du Plessis A., Slabbert R. 2012. 'Looking inside votive creatures: computed tomography (CT) scanning of ancient Egyptian mummified animals in Iziko Museums of South Africa: a preliminary report'. Akroterion 57, pp. 129-148.

[9] Diodore de Sicile, Livre I, LXXXIII-LXXXIV, Bibliothèque historique, trad. Ferd. Hoefer., ed. Delahays, 1851.
[10] Dunand Fr. \& Lichtenberg R. 2017. 'Chapitre V. La pratique religieuse', in : Fr. Dunand, R. Lichtenberg, C. Callou \& Fl. LetellierWillemin, Les chiens momifiés d'El-Deir. El-Deir Nécropoles IV. Editions Cybèle : Paris, pp. 207-229.

[11] Dunand Fr., Lichtenberg R. \& Callou C. 2017. 'Chapitre II. Les momies', in : Fr. Dunand, R. Lichtenberg, C. Callou \& Fl. LetellierWillemin, Les chiens momifiés d'El-Deir. El-Deir Nécropoles IV. Editions Cybèle : Paris, pp. 25-157.

[12] Dunand Fr., R. Lichtenberg, C. Callou \& Fl. Letellier-Willemin. 2018. 'Des chiens et des bandelettes', in St. Porcier, S. Ikram, St. Pasquali (Eds.), Creatures of Earth, Water, and Sky. Essays on Animals in Ancient Egypt and Nubia. Proc. of the Int. Symp. on Animals in Ancient Egypt, ISAAE 1 (01-04 Juin 2016, Lyon/France).

[13] Du Plessis, A., Slabbert, R., Swanepoel, L.C., Els, J., Booysen, G.J., Ikram, S., Cornelius, I., 2015. Three-dimensional model of an ancient Egyptian falcon mummy skeleton. Rapid Prototyping Journal 21(4), pp. 368-372. http://dx.doi.org/10.1108/ RPJ-09-2013-0089.

[14] Falke T.H.M. 1997. 'Radiology of Ancient Egyptian Mummified Animals', in J. van Dijk (Ed.), Essays on Ancient Egypt in Honour of Herman te Velde, Egyptological Memoirs 1, pp. 55-59.

[15] Gnudi G., Volta A., Manfredi S., Ferri F. and Conversi R. 2012. 'Radiological investigation of an over 2000-year-old Egyptian mummy of a cat', Journal of Feline Medicine and Surgery 14(4), pp. 292-294

[16] Harwood-Nash, DC. 1979. Computed Tomography of Ancient Egyptian Mummies. Journal of computer assisted tomography 3(6).

[17] Ikram S. 2017. Animals in ancient Egyptian religion: belief, identity, power, and economy, in: The Oxford Handbook of Zooarchaeology, U. Albarella, M. Rizzetto, H. Russ, K. Vickers \& S. Viner-Daniels, eds. Oxford: Oxford University Press, pp. 452-465.

[18] Ikram S., Slabbert R., Cornelius I., Du Plessis A., Swanepoel L.C. \& Weber H.. 2015. 'Fatal force-feeding or Gluttonous Gagging? The death of Kestrel SACHM 2575'. Journal of Archaeological Science 63, pp. 72-77. http://dx.doi.org/10.1016/j.jas.2015.08.015

[19] Jackowski C., Bolliger S., Thali M.J. 2008. 'Common and unexpected findings in mummies from ancient Egypt and South America as revealed by CT', RadioGraphics 28(5), pp. 1477-1492.

[20] Kompanje E.J.O. \& Smeenk C. 2005. 'Chapter IV. Catalogue of Animal Mummies', in: M.J. Raven and W.K. Taconis (Ed.), Egyptian Mummies. Radiological Atlas of the Collections in the National Museum of Antiquities in Leiden. Palma 1. Brepols Publishers : Turnhout.

[21] König W. Johann Ambrosius Barth; Leipzig: 1896. 14 Photographien mit Röntgen-Strahlen aufgenommen im Physikalischen Verein zu Frankfurt a. M.

[22] Letellier-Willemin Fl. 2017. 'Chapitre IV. Les textiles', in: Fr. Dunand, R. Lichtenberg, C. Callou \& Fl. Letellier-Willemin, Les chiens momifiés d'El-Deir. El-Deir Nécropoles IV. Editions Cybèle : Paris, pp. 187-205.

[23] Lewin PK, Harwood-Nash DC. 1977. Computerized axial tomography in medical archaeology. Paleopath Newsl 17:8-9.

[24] Lortet L., Gaillard Cl. 1903. La faune momifiée de l'ancienne Égypte I, Archives du Muséum d'histoire naturelle de Lyon 8.

[25] Lortet L., Gaillard Cl. 1907. La faune momifiée de l'ancienne Égypte II, Archives du Muséum d'histoire naturelle de Lyon 9.

[26] Lortet L., Gaillard Cl., 1909. La faune momifiée de l'ancienne Égypte et recherches anthropologiques III, Archives du Muséum d'histoire naturelle de Lyon 10.

[27] McKnight L.M. 2010. Imaging applied to animal mummification in ancient Egypt. BAR International Series 2175, Oxford, Archaeopress.

[28] McKnight L.M., Adams J.E., Chamberlain A., Atherton-Woolham St. \& Bibb R. 2015. Application of clinical imaging and 3D printing to the identification of anomalies in an ancient Egyptian animal mummy, Journal of Archaeological Science: Reports 3, pp. 328-332

[29] McKnight L.M. \& Atherton-Woolham St. 2015. Gifts for the Gods. Ancient Egyptian Animal Mummies and the British. Liverpool University Press.

[30] McKnight, L.M., Atherton-Woolham, S.D. \& David, A.R. 2011. The Ancient Egyptian Animal Bio Bank at the $\mathrm{KNH}$ Centre for Biomedical Egyptology, University of Manchester. Antiquity, 85, p. 329. 
[31] Morgan, L. W. \& McGovern-Hoffman, S. 2008. Noninvasive radiographic analysis of an Egyptian falcon mummy from the late period 664-332 BC. Journal of Avian Biology. 39, pp. 584 - 587.

[32] Morgan L., McGovern-Huffman S. \& French-Kreigh P. 2011. 'Comparison of two falconid mummies from the late period of ancient Egypt using noninvasive techniques', Journal of Raptor Research 45(4), pp. 357-361.

[33] Mustra, M., Delac, K., Grgic, M. 2008. Overview of the DICOM Standard. ELMAR. 50th International Symposium. pp. 39-44,

[34] Nicolas, T., Gaugne, R., Tavernier, C., Gouranton, V., Arnaldi, B. Internal 3D Printing of Intricate Structures. in 6th International Conference on Culturage Heritage - EuroMed 2016, Oct 2016, Nicosia, Cyprus. Lecture Notes in Computer Science, 10058 (Part I), pp.432-441,.

[35] Pelizzari Ch.A., Haney Ch.R., Bailleul-LeSuer R., Brown J.P. \& Wietholt Chr. 2012. 'Challenges in CT Scanning of Avian Mummies', in R. Bailleul-LeSuer (Ed.), Between Heaven and Earth. Birds in Ancient Egypt, OIP 35. The Oriental Institute of the University of Chicago: Chicago, pp. 109-118.

[36] Pettigrew Th.J. 1834. A History of Egyptian Mummies, and an Account of the Worship and Embalming of the Sacred Animals by the Egyptians; with Remarks on the Funeral Ceremonies of Different Nations, and observations on the Mummies of the Canary Islands, of the Ancient Peruvians, Burman Priests, \&c., Londres.
[37] Richardin P., Porcier S., Louarn G., Ikram S. \& Berthet D. 2017. 'Cats, Crocodiles, Cattle, and more: Initial Steps Toward Establishing a Chronology of Ancient Egyptian Animal Mummies', Radiocarbon 59/2, pp. 595-607.

[38] Slabbert, R. \& Cornelius, I. \& Colette Swanepoel, L. \& Du Plessis, A. 2012. Looking inside votive creatures: Computed tomography (CT) scanning of ancient egyptian mummified animals in iziko museums of south africa: A preliminary report. Akroterion. 57, p. 129.

[39] Taylor J. 2010. Egyptian Mummies. British Museum Press.

[40] Wade, A.D., Ikram, S., Conlogue, G., Beckett, R., Nelson, A.J., Colten, R., Lawson, B., Tampieri, D. 2012. 'Foodstuff placement in ibis mummies and the role of viscera in embalming', Journal of Archaeological Science 39(5), pp. 1642-1647. http://dx.doi.org/10.1016/ j.jas.2012.01.003.

[41] Ynnerman, A., Rydell, T., Antoine, D., Hughes, D., Persson, A. Ljung 2016. Interactive Visualization of 3D Scanned Mummies at Public Venues, in Communications of the ACM, December 2016, Vol. 59 No. 12 , pp. $72-81$

[42] Zivie A. \& Lichtenberg R. 2005. 'The Cats of the Goddess Bastet', in: S. Ikram (Ed), Divine Creatures : animal mummies in ancient Egypt. The American University in Cairo Press: Cairo/New York, pp. 106-119. 